\title{
INTER-UNION RELATIONS ON THE WATERFRONT: CARDIFF 1888-1914
}

The waterfront in the nineteenth century was notorious for its complex and fragmented labour market. The stevedores on board ship and the porters on the shore were always quite distinct. In London, there were then further divisions, between quay and warehouse workers, between the export and import trades. And within these broad divisions, workers would concentrate upon a particular commodity. Specialisation was rife: the labour-force was a complex body, lacking cohesion because of the diversity of products and functions, the variety of employers, and a casual system which restricted workers to particular localities and types of work. This clearly created problems when unionisation occurred. Each specialism tended to organise separately, and the result would be a plethora of unions somewhat overlapping and competing. In London, again, there was "an endless proliferation of small societies". ${ }^{1}$ And quite apart from the complexity of union organisation amongst the dock workers there were the external relations with on the one side the seamen, and on the other railwaymen and carters. This is all to say that one of the key elements in labour relations on the waterfront before 1914 was inter-union relations.

There were two major periods of militancy on the waterfront - the years following the London dock strike of 1889, and in 1911. Generally speaking, in the first batch of strikes there was no formalisation of relationships between the different groups of workers. If any unity was to be established it usually came from the vaulting ambition of one union - above all the Dock, Wharf, Riverside and General Labourers' Union - to monopolise the organisation of the waterfront.

1 The comments on London are based upon J. Lovell, Stevedores and Dockers. A Study of Trade Unionism in the Port of London, 1870-1914 (1969); ch. 2 discusses the labour-force, and chs 3-5 the problems created for the unions. See also E. J. Hobsbawm, "National unions on the waterside", in Labouring Men. Studies in the History of Labour (1964), p. 210. 
In 1911 there was (on paper at least) a formal organisation, the National Transport Workers' Federation, which had been established in $1910 .^{1}$ Did this create any greater coherence of strategy? What exactly was the pattern of inter-relationship at the two dates? In this paper, the concern is with the experience of Cardiff, a key area which has hitherto been neglected. In some ways, the labour market was less complex than at London or Hull or Liverpool, being dominated above all by one commodity - coal. But even so the divisions found elsewhere appeared in Cardiff to a large extent. Elsewhere, I will consider the problems and policies of individual unions - the seamen, the coal trimmers. ${ }^{2}$ But the central issue in the strikes of $1890-91$ and 1911 was without doubt the relations between the various unions, with the pace being set on both occasions by the seamen.

Each branch of labour of course had its own grievances on hours, wages and conditions of work. These localised claims did not necessarily involve any other group of workers. Neither were employers other than those immediately affected necessarily brought into the dispute. But in some circumstances it might be in the interests of either the employers or the employees to generalise the conflict. In other circumstances, it might be in the interests of one or the other to keep it as specific as possible. If the work group was strategically weak, it was in the interest of those workers to extend the strike on a broader basis. The employers would try to limit the conflict, unless they were very certain of their ability to tackle a broader section of the workforce. But if the work group was in a strong position, with a good case to make for its specific claims, then it might be in the interests of the employers to stress a general principle - particularly that of free labour - in order to confuse the issue and in one fell swoop to tackle any other (and perhaps weaker) unions which might themselves be preparing a programme of specific claims. The workers would meanwhile stress the justice of their specific claims and try to limit the area of dispute. However, generalising a conflict might not always succeed so far as the workers or employers were concerned. Sympathetic action by workers in support of a weak group might lead

${ }^{1}$ The dock strikes can be studied in Lovell, op. cit.; E. L. Taplin, Liverpool Dockers and Seamen 1870-1890 [Occasional Papers in Economic and Social History, No 6] (Hull, 1974); R. Brown, Waterfront Organisation in Hull 1870-1900 [Occasional Papers etc., No 5] (Hull, 1972). On the NTWF, see G. A. Phillips, "The National Transport Workers Federation, 1910-27" (Ph.D. Oxford, 1968).

${ }^{2}$ M. J. Daunton, "Jack ashore. Unionisation of seamen in Cardiff before 1914", in: Welsh History Review, forthcoming; id., "The Cardiff Coal Trimmers Union 1888-1914", in: Llafur, forthcoming. 
not to a victory for the occupation in question, but to a widening of the area of defeat. And the employers similarly had to be very careful. The decision as to when a general or specific approach was required was, in other words, a difficult one.

Labour historians have concentrated on the relationships between employers and employees. But relations amongst the employers and amongst the workers could be as important as relationships between the two. On the union side there might be bitter conflicts as one sector tried to bring out others against what might appear to be their best interests, or as one union tried to drive out a sectional union and take over a strategic occupation to improve its position. On the employers side, there would also be different interests, between those directly employing a group which demanded certain changes, and those threatened with disruption if a strike occurred - the one might favour confrontation and the other conciliation. The rest of this paper will indicate exactly how these general considerations applied in practice to the case of Cardiff; they might equally be applied to London or Liverpool or Hull.

The most important branch of dock work in Cardiff was the loading of coal. This was the very raison d'être of the port. ${ }^{1}$ But the coal trade, despite its strategic importance, did not employ the majority of men engaged at the docks, for it was mechanised to an extent unusual for dock work. A basic distinction is to be made between the strategic capital-intensive sector dealing with coal, which employed a minority of the workforce, and the miscellaneous but labour-intensive non-coal trades and ancillary services, at which the majority of dockers were engaged. In addition, there were distinctions within each sector: in the coal trade between the quayside and ship-board workers; and within both the coal trade and the miscellaneous occupations between the men engaged directly by the dock company and those employed by the various merchants and ship-owners. The dock authorities had in 1882 attempted to bring all labour at the docks under one uniform system, but had failed, and it was the persistence of these divisions which was to provide the framework for unionisation of the dockers up to $1914 .^{2}$

1 On the development of the port, see Daunton, "Aristocrat and traders: The Bute Docks, 1839-1914", in: Journal of Transport History, New Series, III (1975); id., Coal Metropolis: Cardiff 1870-1914 (1977).

${ }^{2}$ For the scheme of 1882, see Minutes of Evidence, House of Lords and House of Commons, 1882, Bute Docks Bill, House of Lords Record Office. 


\section{Dock workers in Cardiff c. 1894}

Coal

$\begin{aligned} & \text { Deal porters } \\ 300 & \text { Deal yardsmen } \\ 1,000 & \text { Pitwood workers } \\ & \\ & \text { Geneval } \\ 300 & \text { Hobblers, riggers, boatmen } \\ 200 & \text { BDC employees (excluding } \\ 350 & \text { tippers) }\end{aligned}$

Tippers

Trimmers

300

Non-coal

Corn porters

Stevedores

Iron ore

350

Deal porters

500

400

Source: WTUC/A (see below, p. 355, note 2), Vol. IV, ff. 75-90; Royal Commission on Labour, Answers to Schedules of Questions, Group B, p. 85. These figures are very approximate, and only indicate the rough order of magnitude.

The loading of coal involved two completely separate groups of men, the tippers or quayside workers, and the trimmers or shipboard workers. The trimmers distributed the coal in the hold of the ship once it had been tipped out of the railway wagons using a fairly simple tipping machinery, which in the early days had simply used gravity but which by the 1880 's was predominantly hydraulically powered. The quayside work was a highly mechanised process, the tippers' work involving a fairly simple and straightforward operation of levers to regulate the raising and upending of railway wagons. Men were not at all interchangeable between the two groups, and there were a number of important differences. Essentially, the trimmers worked in gangs engaged to deal with a particular ship and paid on a tonnage basis, under the dual control of ship-owners and coal freighters. The tippers, by contrast, were in the regular employ of the dock proprietor (except for the oldest dock, where the Taff Vale Railway was the employer) and paid on an hourly basis. This divergence between the two occupational structures was to determine the nature of their unions and their experience of labour relations.

The non-coal trades and the miscellaneous port services also had two broad categories. The dock authority itself employed 1,500 men in 1892. In addition to the coal tippers, there were mechanics, railwaymen, dock gatesmen, police, cranesmen, dredgers and labourers. These were predominantly regular men. On the other hand were the predominantly casual workmen controlled by a variety of employers. The hobblers, riggers and boatmen moved the ships around the docks, and provided the necessary shipboard servicing required whilst in dock. They would wait at the harbour entrance to offer their services to ships' captains as they arrived, and would be engaged either for each move or be paid a lump sum to look after the ship until it left. Then there were the labourers engaged by merchants in various 
branches of trade to load and unload their produce - timber, pitwood, grain, iron ore, patent fuel. These were, with the exception of iron ore, totally unmechanised, and even iron ore was much more labourintensive than coal. It was these trades which employed the bulk of the dockers, although they were of little strategic importance and handled only about a quarter of the total trade. ${ }^{1}$

The employment structure within the docks was thus complex. And on top of this there were the seamen and railwaymen. When in 1897 the Bute Docks Company became the Cardiff Railway Company, its employees became, as it were, honorary railwaymen. The Bute Docks were serviced by a number of lines - the Taff Vale, Rhymney and Great Western -, whilst the Barry Railway served the dock system a few miles to the west at Barry. If the BDC employed railwaymen, and had a vested interest in what happened on the lines upon which it was so dependent, then the Taff Vale Railway as lessee of the Penarth Docks, and the Barry Railway Co. as proprietor of the Barry Docks, both employed dockers. ${ }^{2}$ The railwaymen's union had its own problems in keeping a coherent policy amongst the four companies, a task which was often made even more difficult by divisions within each company by grade and location. ${ }^{3}$ But at least railwaymen were regular employees: the seamen were an ever-changing group of temporary residents. Cardiff was a "hard-up" port, a town to which impecunious seamen went in search of a berth. This, the racial mix, and the openness of the labour market, were barriers to unionisation at other than exceptional times. Indeed - as has been indicated elsewhere in more detail - the extreme vulnerability of the seamen meant that alone they could achieve very little. ${ }^{4}$ These considerations in respect to the railwaymen and seamen imply a pressure from respectively the employers and workers to extend conflicts to involve the dockers. So would-be organisers of the dockers had to contend not only with the internal fragmentation of the waterfront, but also with

1 J. McConnochie, The Bute Docks Cardiff and the Mechanical Appliances for Shipping Coal (1885, reprinted from Proceedings of the Institute of Mechanical Engineers, August 1874) ; Royal Commission on Labour, Minutes of Evidence, Group B, Vol. II [Parliamentary Papers, 1892, XXXVI/II], qq. 13760, 13790-91, and Answers to Schedules of Questions, Group B [PP, 1892, XXXVI/III]. pp. 85, 101; Minutes of Evidence, as above, p. 352, note 2, House of Lords, speech of counsel for Bute, qq. 1553-55, 1558-61, 1612, 1616; House of Commons, qq. $520,580-82,827,1524,1576,1640,1647-48,1736-37,1892,3066-243,5909$, 6112, 6246-502, 6572-710, 7446-98, 7522-24, 7549, 7551-844.

2 Daunton, "Aristocrat and traders", loc. cit.

${ }^{8}$ This is dealt with at length in M. J. Daunton, "Aspects of the Social and Economic Structure of Cardiff, 1870-1914" (Ph.D. Kent, 1974). Pt 4, ch. 5. "See Daunton, "Jack ashore", loc. cit. 
the additional complications of the backward and forward linkages.

Cardiff differed from Hull, Liverpool or London in that no waterfront unions had survived from the early 1870's. The dock company's attempt of $\mathbf{1 8 8 2}$ to change control of the labour-force had led only to a temporary ad hoc body despite some attempts to extend its role. ${ }^{1}$ So the unions created in 1888-89 were not building on any preexisting foundation. The unions formed then were both local and national. The first to emerge was a local union of the trimmers set up in 1888. It was followed in 1889 by a local union of tippers, another of hobblers, riggers and boatmen, and the (purely local in spite of its name) National Amalgamated Labourers' Union, which organised some dockers but was mainly active in other sectors. In October 1889 the genuinely national Dock, Wharf, Riverside and General Labourers' Union (hereafter Dockers' Union) established a branch. ${ }^{2}$ Clearly, in order to estabish itself, the Dockers' Union had to win members from the two strategic sectors - the tippers and trimmers. If possible, its ultimate ambition was to monopolise the waterfront, an "overbearing domineering character" which was much resented by other unions. ${ }^{3}$ In 1890 the tippers did enter the Dockers' Union, and there seemed a good chance that the local organisation of trimmers could be broken.4 Of the non-strategic groups, grain, pitwood, timber, patent-fuel workers were well organised by the national union. ${ }^{5}$ Ben Tillett could boast in July 1890:

"We are strong enough to tie the hands of merchant, shipowner and dock proprietor, and if the demands of our men are not allowed, this course will be adopted to bring them to a sense of the great change in the labour market." 6

Accordingly, demands were submitted to the employers and a reply requested by 6 August $1890 .^{\text {? }}$

The timing of the strategy of the Dockers' Union was, however, to depend initially upon the railwaymen and subsequently upon the

${ }^{1}$ Lovell, Stevedores and Dockers, ch. 3; Brown, Waterfront Organisation in Hull, op. cit., ch. 2; Taplin, Liverpool Dockers and Seamen, op. cit., p. 1; Daunton, "Aspects", op. cit., II, pp. 45-48.

2 Webb Trade Union Collection, Section A (hereafter WTUC/A), Vol. IV, ff. 75-90; Vol. XLII, ff. 46-51, British Library of Political Science; South Wales Daily News (hereafter SWDN), 11 December 1889; 1 and 18 March 1890; Minute Books of the Cardiff Coal Trimmers Union, Miners Library, Swansea.

WTUC/A, Vol. IV ff. 75-90.

SWDN, 18 March, 19, 24, 25 and 30 July, 1 August 1890.

5 Ibid., 18 March.

Ibid., 25 July.

7 Ibid., 24 and 31 July, 1, 4 and 5 August. 


\section{Membership of the Dockers' Union in Cardiff}

$\begin{array}{lll}\text { April } 1890 & 5 \text { branches } & 1,000 \text { members } \\ \text { July } 1890 & 8 \text { branches } & 2,302 \text { members } \\ \text { January } 1891 & & 3,824 \text { members }\end{array}$

Source: P. W. Donovan, "Unskilled Labour Unions in South Wales, 1889-1914" (M.Ph. London, 1969).

seamen. A local branch of the National Amalgamated Union of Sailors and Firemen was established in 1888. It had 1,000 members by the end of the year, 6,000 by mid 1890 . The introduction of the union, with the concurrent rise in freight rates, led to a rapid increase in wages. But it was only in the second half of 1890 that the employers' counter-offensive began in earnest, leading to the strike of $1891 .^{1}$ Before this, the pattern was established by the railwaymen. Unlike the waterfront, there had been some continuity of organisation: the Amalgamated Society of Railway Servants had established a branch in 1872. But during the 1880's the ASRS had not taken a very active role, the pattern being one of fragmentation between ad hoc organisations of various grades on each line. It was in 1889 that the ASRS started to take control again. At the end of the year the Society's national programme was adopted by a local mass meeting. The demands for a guaranteed weekly wage, a ten-hour day (shorter for some grades) and overtime were submitted to the local railway companies, but were either completely ignored or met with the bland reply that employees could consult the directors at any time. Eventually, two companies did meet deputations and offered concessions which were regarded as inadequate. The next stage was to request arbitration, but this was either ignored or refused. Accordingly, notices were handed in, to expire on 6 August. The companies refused to negotiate during the period of notice, and were quite content for the two weeks to expire and the strike to commence. ${ }^{2}$ This created a problem for the Dockers' Union, which was pledged to support the railwaymen: ${ }^{3}$ exactly how should they proceed with their own claims which matured on the same day as the railway strike began?

The Dockers' Union had already run into difficulties with W. T. Lewis, manager of the BDC. Lewis was claiming that the union was

1 Daunton, "Jack ashore".

2 Daunton, "Aspects", II, pp. 207-10; SWDN, 20 April and 9 December 1889; 14 February 1890; P. S. Bagwell, The Railwaymen (1963), p. 137; L. J.Williams, "The new unionism in south Wales, 1889-92", in: Welsh History Review, I (1960).

3 SWDN, 4 August 1890. 
demanding a closed shop. This the union denied: it just wanted a reply to its claims and negotiations through Ben Tillett, which was of course tantamount to union recognition and so anathema to Lewis. Lewis was quite deliberately building up to a conflict on a general principle of "free labour" rather than over specific grievances concerning wages and hours of work. The local Liberal newspaper saw him as a greater firebrand than the union leaders, indulging in "a determined and deliberate policy of embitterment". Lewis inaccurately informed William Riley, the president of the Chamber of Commerce, "that a large number of the men demanded that the dock company should agree to employ none but trade unionists before they would discuss any of the special points which they desired me to consider". Riley replied:

"Be assured the merchants of the port will strengthen your hands by every means in their power, even to a general lock-out, rather than you should be forced to concede to the trades unionists the demand they urge that free labour be excluded from the Bute Docks."'1

Tillett, in the face of such attitudes, decided to suspend the claims of the dockers until the railway strike was over rather than jeopardise the railwaymen. ${ }^{2}$ In addition, the strike had brought the docks to a standstill, so that the dockers were in no position to threaten disruption in support of their demands. But the decision was strategically sound for another reason. Riley and Lewis wanted to attack the seamen, dockers and railwaymen together on a general principle of "free labour". Coal shippers and other merchants could argue that since there was a dislocation of trade anyway, why not take on as many as possible and on as wide an issue as possible? And the dual interests of the dock and railway companies made this particularly appealing to them. The ship-owners for their part were preparing to break the seamen's closed shop, and saw the railwaymen and dockers as part of the same threat to "free labour". The Shipowners' Association passed resolutions protesting "most strongly against the arbitrary and tyrannical conduct" of the various unions, expressing the opinion "that the time has arrived when, in the interest of the port and of commerce generally, a firm and continued stand should be made". The Association bound itself "to use all legitimate means to preserve for employers the right to engage free labour", and expressed its solidarity with the railway and dock companies.

2 Ibid., 8 August. 
The Riley-Lewis attitude was best expressed at a meeting of the Chamber of Commerce on 11 August 1890. Riley stated the problem to be "a great combination of unionists to shackle and demoralise the trade and commerce of Cardiff". The dockers, railwaymen and seamen could not be treated separately. While he accepted the demands of the railwaymen to be justified, he felt that they could not be conceded because of the whole question of free labour: whatever Tillett might say, he was in practice preventing non-unionists from obtaining work, and any concessions to the railwaymen would further encourage him. On this question of free labour there was general agreement - the problem was "an enormous and gigantic conspiracy against the rights of labour by the organisers of the trades unionists". One leading coal-owner did express the view that it was irrational to oppose reasonable claims from a fear that there might later be unreasonable claims from another quarter. But there was a rationality: why not in one fell swoop and on an issue of principle on which the unions were on weak ground take on all groups? A resolution that each dispute should be considered separately was in fact overwhelmingly defeated. Tillett's decision to waive his demands, however, made it rather more difficult to equate the admittedly reasonable claims of the railwaymen with the seamen and dockers, and so strengthened the position of the railwaymen. The unions saw that it would be better to fight this "hybrid combination of capitalists" sectionally, on the merits of each case. So the railway strike was not generalised, and the dockers and seamen had still to be faced. ${ }^{1}$

As far as the railwaymen were concerned, as soon as the strike began, the chairman of the Taff Vale Railway board arranged a meeting with the general secretary of the ASRS. Within a day they had reached agreement, which was, however, rejected as inadequate by a mass meeting of strikers. Subsequently, both were given full powers to make a settlement. The outcome was not a complete victory: no demand was achieved in full despite the complete stoppage of the railways and dislocation of collieries and ports. Nevertheless, it did appear as a marked victory in another sense, for apparently the ASRS had won recognition. That a union official, someone who was not an employee, could make a binding agreement on behalf of a company's staff was something hitherto rigorously opposed by the railway companies. Now they had given in and it seemed a major breakthrough. However, after a few years this was seen to be a temporary aberration rather than a permanent achievement. ${ }^{2}$

1 Western Mail, 12 August 1890.

2 Bagwell, The Railwaymen, op. cit., pp. 138-39; Daunton, "Aspects", II, pp. 212-14; Williams, "The new unionism", loc. cit. 
The end of the railway strike allowed the dockers to resume work, but with their claims still outstanding and without the reply requested by 6 August. ${ }^{1}$ Railwaymen and dockers had not been tackled together. It now remained to be seen how the dockers and their employers would respond. Would the dockers emulate the success of the railwaymen; would the employers try to crush them now the railwaymen were content? At first, in fact, the general temperature seemed to be reduced. The Chamber of Commerce, having suffered one crippling strike, now hoped to prevent the anticipated strike of dockers and passed a resolution "that a committee be formed to consider with the representatives of capital and labour in the district the formation either of conciliation boards or of a general conciliation board for the settlement of disputes". The dockers had stood aside to allow the justice of the railwaymen's demands to be recognised without being merged with their claims. These now seemed capable of solution in a conciliatory fashion. Coal-owners in particular, whose production has been disrupted once, were not willingly for it to happen again: a generalised conflict was rational when they had already been forced to stop work, but a series of specific confrontations would be crippling. For his part, Tillett felt that there was a mutual desire on all sides for the formation of a conciliation board. He remarked:

"It seems to me that a board of conciliation is the only means to bridge the gulf between capital and labour. A determination to face and grapple with these problems of labour, with all the powers of brain and heart, instead of sulking and scowling, mean the strengthening of the bonds of good feeling and robustness, which must inevitably tend to the moral, social and industrial advancement of the individual and the nation alike."

Encouraged by this favourable union response, the Chamber of Commerce appointed a committee to bring together employers and men to form such a board. ${ }^{2}$ However, the scheme ran into insuperable problems and collapsed in November 1890.

The prime stumbling block was representation of non-unionists. Although all negotiations had been with the organised workers and

1 SWDN, 16 and 18 August 1890.

2 Ibid., 12, 18 and 26 August; Western Mail, 12 August; Bute Papers, IX 33, entry for 21 August 1890, Cardiff Central Library; Cardiff Chamber of Commerce, General Minutes 1884-92, monthly meeting of 20 August 1890, and Report of the Committee appointed on 20 August 1890 to consider with the representatives of capital and labour in the district, the formation either of conciliation boards or of a general board for the settlement of disputes, Glamorgan Record Office, $\mathrm{D} / \mathrm{D} \mathrm{Com} / \mathrm{C}$. 
union officials, the Chamber of Commerce committee "had no desire to exclude non-unionists". And the railway companies were "determined to sanction no scheme for a board the workmen's representatives on which should be elected by unionists only". In November the Trades Council wrote that it had "finally decided not to take any part in such board which would be composed of unionists and nonunionists". The Chamber's committee felt that such "a partial representation" and "disability in respect of free labour" was unacceptable and dropped the proposal. The Trades Council had in fact at one stage agreed to each trade electing a member of the board "irrespective of their being unionists or non-unionists", so responsibility for the collapse of the scheme seemed to rest firmly with the Trades Council.

In fact, if the Trades Council had waited, collapse would have been brought about from the employers' side by a divergence within their ranks. The coal freighters dominating the Chamber were simply customers of the docks eager to avoid the disruption of a strike, but the railway and dock companies directly involved were less eager to support the scheme. Insofar as the latter went along with the negotiations, it was with respect to the particular scheme being proposed by W. T. Lewis. He had drawn up a draft scheme for a "Bristol Channel Docks Association of Employers and Workmen". This was to promote harmony, prevent strikes, and regulate labour and wages. The proposal was that a joint committee of directors of the local docks, those employing labour at the docks, and workmen, was to establish wages and determine contracts which were not to be altered without the permission of the joint committee, whose decision was binding. There was also to be a sick and accident fund, to which employers would contribute a certain percentage of wages. Lewis "would be no party to a scheme apart from a benefit fund, to which workmen and employers should alike contribute". This was not the type of scheme sought by the Chamber's committee, and would probably not have been accepted by most employers; certainly, it would have been anathema to the unions, whose position it was deliberately designed to undermine. ${ }^{1}$

During this interval, Tillett submitted the official claims of the Dockers' Union, with a deadline of 4 November. But the union failed to pro-

1 SWDN, 9 and 11-13 September, 20 and 25 November 1890; Royal Commission on Labour, Minutes of Evidence, Group B, Vol. II, q. 13757; Cardiff Chamber of Commerce, Report of the Committee appointed on 20 August 1890; Executive Committee Minute Book 1890-95, meeting with Trades Council, 14 October 1890. 
secute the claim in an effective manner and, in the absence of its officials, the tippers and cranemen took matters into their own hands by announcing that they would strike failing a settlement by $8 \mathrm{De}-$ cember. The tippers would clearly be in breach of contract by failing to work out their notice, and it was well known that the BDC had already laid on a supply of blackleg tippers. However, at the last moment, the tippers (unofficially) and the BDC did reach an agreement which abandoned most of what they wanted for a few minor concessions. The agreement was denounced by the union and never ratified, but it had created a difficult position. The union was raising the vexed question of "free labour" and recognition, whilst the BDC could claim that all differences had been settled, that the problem was simply the union stirring up difficulties between masters and men after they had reached agreement. ${ }^{1}$ A further complication was that during this period the trimmers' union had negotiated a new tariff with the employers, which gave them full recognition and an established position on the waterfront.

If the dockers made a correct tactical decision with regard to the railway strike of 1890 , then a gross tactical error was made in respect to the seamen's dispute of 1891 , which placed the union - more particularly the tippers - in the hands of W. T. Lewis. Parallel with the increasing tension between the tippers and the BDC there was an increase in the tension between the ship-owners and the seamen's union. Initially the seamen had secured a large increase in wage rates, and been largely successful in enforcing a closed shop. The assault of the ship-owners was at first against the closed shop, starting in the latter part of 1890 , but finally resulting in a strike in 1891. In January 1891 the seamen's union resolved that "the ships of all the companies who oppose this union should be blocked". ${ }^{2}$ Next month, a mass meeting of the seamen's union, the riggers, the National Amalgamated Labourers' Union and the dockers resolved

"That in the opinion of this representative meeting the time has arrived when the ships of any particular company who shall declare in favour of engaging labour other than that recognized by the Trades Council of the several districts in or about their ships shall be blocked. That all members of the unions represented

${ }^{1}$ SWDN, 8 September, 31 October, 7 and 8 November, 5, 6, 8, 9, 12 and 22 December 1890; 5 January and 20 February 1891.

2 Daunton, "Jack ashore"; SWDN, 29 July, 30 and 31 October, 1, 4, 6 and 7 November $1890 ; 21$ January 1891; Cardiff Shipowners' Association, General Minute Book 1890-1902, 6 August 1890 (ff. 5-6), 12 August (ff. 7-8), 15 August (f. 9), 25 September (f. 16), Glamorgan Record Office, D/D Com/C. 
at this meeting shall cease work upon being notified to this effect by the officials of their respective unions."

The next day, officials of the dockers' and seamen's unions went to the steamship Glen Gelder and requested it to sign a union crew. When this was refused, the ship was blocked by the tippers and riggers. ${ }^{1}$

The tippers, who had failed to strike in support of their own reasonable claims, had now come out to enforce the seamen's opposition to non-union labour. It was exactly this issue of "free labour" which the employers had sought to make central to the earlier railwaymen's dispute, rather than the justice of the demands made. In 1890 the confusion had been avoided and the dockers stood aside. But in 1891 the tippers were explicitly striking to exclude non-union labour, so the struggle was between free and union labour - the tippers had in fact not even resubmitted their own wage demands. Further, they had left work without notice, and the BDC took out summonses. All the tippers consequently left work to join those involved with the Glen Gelder, fighting both the battle of the seamen against the Shipping Federation, and for their own survival against the BDC. The BDC for its part was fighting the battle of the Federation to employ nonunion labour. Blackleg tippers were immediately introduced and all the tips put into use. The BDC was determined to keep the Glen Gelder in dock and to provide full services to the ship-owners. The position of the BDC was clearly stated, that

"all labour at the Bute Docks must be regarded as absolutely free, and that no preference will be given either to unionists or non-unionists, and particularly that the company cannot directly or indirectly recognise any attempt to put pressure upon other employers or workmen as to the terms upon which they are to carry on their businesses."2

The attitude of the trimmers was to be crucial. In fact, they remained loyal to the Cardiff Coal Trimmers' Union and continued to work with the blackleg tippers. According to Tillett, the CCTU was an organisation controlled by "the foremen and their 'fancy men"', not a genuine union:

"the Trimmers' Association was a benefit and sick society practically, and its officials were more or less middlemen [...]. The power the other society was demonstrating on paper had very

1 SWDN, 3 and 4 February 1891.

2 Ibid., 5-7 and 12 February; Royal Commission on Labour, Minutes of Evidence, Group B, Vol. II, q. 13750, and Answers to Schedules of Questions, Group B, p. 116. 
little substance, and for all practical purposes of determining whether or not there should be a strike the union had very little power, because it was not a trades union."

At one time just over a thousand trimmers were in the Dockers' Union against 1,300 in the CCTU. But in 1891 it was clear who in the final analysis controlled the trimmers. The CCTU refused all pleas from the dockers - without exception the trimmers remained at work and the coal trade was not stopped. The trimmers' union secretary said that to extend the strike would be "positively wicked", and recommended others to follow the CCTU policy of moderation and courtesy. The trimmers' attitude was that the seamen's dispute was no concern of theirs and that they should remain "neutral". To the other unions, it was absurd for any union to claim it was neutral in a dispute which was over the very principle of unionism. As J. Havelock Wilson said, it was impossible for the CCTU to trim coal tipped by blacklegs and remain true to its professed trades-unionist principles, although "of course the employers would give them an encouraging pat on the back and would call them worthy trimmers, true to law and order, and would say "we respect you"'. It was an attitude which persisted - with similar attacks for being traitors when in 1912 and 1913 the CCTU was one of the few unions which refused to join the National Transport Workers' Federation. ${ }^{1}$ Why did this strategic group abandon the Dockers' Union and remain at work? There were in fact very good reasons which have been explained in detail elsewhere. The explanation has two sides: one, the internal structure of the trimming workforce; the other, external relations with the employers.

Internally, the trimmers were divided into three groups - the foremen, gangmen trimmers and casual trimmers. The foremen controlled entry to the gangs, charging a premium and usually taking one share in the gang's earnings, although most also had a salary. The gang earned a lump sum depending on the number of tons loaded, so the policy was to keep the number sharing in the lump sum to the minimum so that each had a large income. If necessary, casual trimmers would be engaged when the gangmen could not handle the coal; they were engaged on an hourly basis, and did not share in the lump sum. This set-up caused a number of tensions. On the one hand, the casual trimmers felt exploited by the gangmen - their employment was irregular, and whilst they might be doing a large part of the actual work they were not getting a proportionate share of the income. On oc-

1 WTUC/A, Vol. XLII, f. 139; SWDN, 30 July, 1 August, 8 and 10 November $1890 ; 7,11,12$ and 20 February, 3 March 1891. 
casions they therefore threatened revolt and broke away from the union. On the other hand, the gangmen were in a dilemma. They had to make concessions to the casuals, and this would include an attack upon the foremen, whose share the gangmen in any case resented. But in the final analysis, the foremen controlled entry to trimming and had to be placated. These cross-cutting tensions were important in the years being discussed. When it was formed in 1888, the CCTU contained foremen, and it was largely an institutionalisation of the alliance between the gangmen and foremen. In 1890 it was the casuals who revolted and joined the Dockers' Union, which was strongly attacking the foremen - and for a time the gangmen followed. In a crisis, however, it was clear where their interests lay, and they remained loyal to the CCTU. The foremen were banned from membership in 1895 when it seemed safe to do so, but in 1891 the importance of the foremen in controlling the entry of labour had to be recognized and the gangmen could not go along with the Dockers' Union.

The other important consideration was the external relations with the employers. Here the trimmers had to play the ship-owners off against the coal shippers. The trimming tariff was fixed by the coal shippers, but was actually paid by the ship-owners. So the employment structure was divided and, unlike the tippers, the trimmers did not face a single employer who fixed the wages and controlled entry to the labour market. The two employing groups had different interests. Trimming was considered a valuable service by the coal shippers, who stressed the friable nature of Welsh steam coal and the consequent need for careful handling, while the ship-owners considered the service was increasingly marginal with the introduction of socalled "self-trimming" ships so that they wanted to end trimming or at least greatly reduce the tariff. The policy of the trimmers was therefore to play the coal shippers off against the ship-owners, to prevent them uniting against the trimmers. A policy of militancy would endanger such a strategy, and was accordingly shunned. The policy of moderation to which the union adhered was in fact much more functional than the militancy its critics urged. In 1890 the CCTU secured a favourable tariff, recognition and a board of conciliation. Loyalty to the CCTU and abandonment of the Dockers' Union had paid dividends. ${ }^{1}$

With the trimmers still at work, and blacklegs manning the tips, coal continued to be loaded onto ships. The seamen had gained nothing, whilst the Dockers' Union had placed itself in a parlous position. 1 The last two paragraphs are based upon "The Cardiff Coal Trimmers Union", loc. cit. 
All union seamen - who had hitherto not been on strike but only refusing to sign on non-union ships - were now called out, to fight their own battle against the Shipping Federation and also to help the tippers whose sympathy was costing them so dear. No union seaman was to sign on whilst the BDC employed blackleg tippers. The dispute had switched from the dockers versus the BDC (initially as proxies of the seamen and ship-owners) to the seamen versus the ship-owners in their own right, but also with the seamen pledged to help the dockers against the BDC. As the local newspaper said, "the cause of the dispute has not that definiteness and clearness which wins sympathy. The fight is not for wages or hours but what is regarded as a principle of unionism." The Dockers' Union was made to appear an aggressor, and, even worse, an unjustified aggressor, for the BDC could claim that a settlement had already been made, that there were no outstanding grievances, and that it was simply a union assault on free labour. ${ }^{1}$

When Tom Mann arrived to take charge, he came to the conclusion that the Shipping Federation's attitude to the seamen's union was quite justified. But he could not simply abandon the seamen and return to work, for the dockers were now fighting for their own survival, with little prospect of gaining redress of their own grievances. Indeed, if Mann was to save anything, he had to extend sympathetic strikes, to cut off the supply of coal by eliciting the support of the ASRS and the miners. The seamen concurred in this, and the policy had the support of the strike committee at the docks. An approach was accordingly made to both unions.

The miners were not likely to be sympathetic. Since the collapse of Halliday's union in the early 1870's, the tone of labour relations had been set by William Abraham - "Mabon". His attitude was very much one of moderation and mutuality, of working hand in hand with the coal-owners in determining wages by the selling price of coal through the medium of the sliding scale. It was an attitude which only started to be threatened by the late 1890's. And the leading figure on the coal-owners side was Sir W. T. Lewis, in his other role of owner of the Aberdare Coal Company. From its formation he was chairman of the sliding-scale committee, with which both he and Mabon were inextricably linked. He had introduced for the miners something like the scheme he had wanted for the dockers. The miners were not likely to be very keen on a sympathetic strike. Their organisation was simply not on such a basis. Their response was accordingly to recommend that the strike committee call a conference of 1 SWDN, 11, 13 and 20 February 1891; Minutes of Evidence, as above, p. 362, note 2 . 
South Wales unions to discuss the dispute. The ASRS concurred with this policy. When the conference met, it was not impressed with the seamen's case against the Shipping Federation, and recommended that they accept the Federation's terms and return to work. To Wilson's disgust, they had no option but to do so - the closed shop was broken and the union defeated. As for the tippers, Mabon and the general secretary of the railwaymen met Lewis to seek their reinstatement. This he refused, but he did agree that they would be considered as vacancies arose. On this basis, the conference passed a resolution recommending the termination of the dispute. ${ }^{1}$

At the end of 1890 and early in 1891 something on the lines of the later NTWF was in the air, largely in response to the establishment of the Shipping Federation. A conference met in London at the end of 1890, which resulted in the formation in January 1891 of the Federation of Trade and Labour Unions connected with the Shipping, Carrying and other Industries. This extended on a national basis, and had 41 members by 1893. It was hoped that the conference ending the strike at Cardiff would provide the basis for such a federation of related trades, from the seamen through the dock workers and railwaymen to the miners. However, the indifference of the Welsh miners under Mabon, the caution of the railwaymen both then and in 1892, not to say the collapse of the dockers and seamen, meant that this never had any chance of success. The "South Wales and Monmouthshire Federation of Trades and Labour Unions" did have a fleeting paper existence, but was of no practical significance. This does at least indicate that the same forces were operating in 1891 as were, after the next major outburst of militancy in 1911, to lead to more viable federations covering these work groups, namely the NTWF and Triple Alliance. ${ }^{2}$

The dockers had suffered a disastrous defeat. The claims of 1890 were still outstanding and the union broken. By 1894 the union was down to 50 members where at one time it had 4,000 members in Cardiff, Barry and Penarth. ${ }^{3}$ It is difficult to escape the conclusion that the strike of tippers was a massive tactical error. Because the men's

1 SWDN, 13, 14, 16-20, 25 and 26 February, 2-5 March 1891; E. W. Evans, Mabon. A Study in Trade Union Leadership (1959); id., The Miners of South Wales (1961).

${ }^{2}$ Williams, "The new unionism", pp. 425-26; H. A. Clegg, A. Fox and A. F. Thompson, A History of British Trade Unions since 1889, I: 1889-1910 (1964), pp. 74-75; Lovell, Stevedores and Dockers, pp. 143-44; P. S. Gupta, "Railway trade unionism in Britain c. 1880-1900", in: Economic History Review, Second Series, XIX (1966), pp. 134-35; C. Edwards, "Labour federations", in: Economic Journal, III (1893), pp. 208, 419-20, 424; SWDN, 5 March 1891.

${ }_{3}$ WTUC/A, Vol. IV, ff. 75-90. 
claims had been allowed to continue too long, there had been unofficial action at the end of 1890 , which only served to confuse matters, and the strike was finally called at an inopportune moment and on the wrong issue. As an "Old Tipper" wrote in the aftermath of the strike:

"The tippers were driven to desperation, not about the Glen Gelder but because they could not see Sir W. T. Lewis and the case of the Glen Gelder turned up and they struck work, thinking it would be the means of inducing Sir W. T. Lewis to arrange an interview. However, we made a mistake, a very serious mistake - we now acknowledge it. What we ought to have done was not to strike on account of the Glen Gelder but to strike for our own demands which were acknowledged to be very reasonable."1

The crucial factor had been the decision of the trimmers to work with the blackleg tippers. If they had not - and since they did have a significant role on ships other than self-trimmers which were then still in their infancy -, then Lewis's use of imported labour would have been less successful. The tactical error of striking over the Glen Gelder was compounded by this serious strategic weakness. And this could not be made good by extending the strike either to the source of coal or to the railway lines linking pit and port. Clearly, the actions of one union impinged on the position of the other, but there was as yet no way of forming a coherent strategy. Were there any lessons here for the next major strike on the waterfront?

\section{II}

The defeat of 1891 ended the seamen's and dockers' unions as serious forces on the waterfront for two decades. Spasmodic attempts were made at revival, but they were always short-lived and unsuccessful. ${ }^{2}$ And the railwaymen in the years after the "victory" of 1890 were scarcely more successful. The recognition which had apparently been secured was lost within a few years, and there was a return to fragmentation and "adhocism", which was reinforced by the mishandling by the general secretary of the dispute on the South Wales lines in the winter of 1899-1900. This episode confirmed the local railwaymen in the belief that they should be responsible themselves for any future action - an attitude which led to the disastrous Taff Vale Railway strike of 1900, when the absence of any firm overall control played into the hands of the company. The railwaymen only started to recover

1 SWDN, 13 May 1891.

2 See Daunton, “Aspects", II, pp. 64-70, 173-88. 
with the all-grades movement of 1906-07 and the national strike of 1911. ${ }^{1}$ Meanwhile, the miners had moved away from the philosophy of Mabon and adherence to the sliding scale, a trend which culminated in the Cambrian dispute of 1910-11. ${ }^{2}$ As part of this general movement towards militancy, the waterfront was also reorganised.

In September 1910 the following resolution was passed by a conference of seamen and dockers:

"That it is desirable and necessary that immediate steps be taken to establish a federation of all unions in the transport industry. That the objects of the federation shall be the controlling and conducting of disputes in the trades and occupations covered by the federation. That a stop be put to the unwarrantable competition between unions for members in the same occupations and that the federation shall gradually stop the overlapping of unions." 3

An important influence on this was the mounting tension during 1910 in the Bristol Channel docks, particularly at Newport and Bristol. The strike at Newport in May and at Bristol in July involved the Shipping Federation against dockers as well as seamen. ${ }^{4}$ Meanwhile in 1910 the seamen were planning an international strike in collaboration with the European unions. In April 1911 the international committee decided on strike action if the International Shipping Federation ignored its demands. The British Federation did indeed refuse to consider the seamen's demands, but German, Danish and Norwegian owners did make concessions and the international movement collapsed. ${ }^{5}$ So one side of the seamen's support had gone - but in the absence of international solidarity there appeared to be solidarity on the waterfront.

In fact, the seamen's union jumped the gun. The strike was called at Cardiff on 14 June 1911.6 International support was absent - and so was support from other unions on the waterfront, who had simply not been consulted and who accordingly remained at work. As in 1891, so in 1911 the precipitating factor was the action of the seamen. It was in response to the strikes of seamen at Cardiff and elsewhere that the NTWF had to call a conference in London on 28 June, which decided

1 Ibid., Pt IV, ch. 5; Bagwell, The Railwaymen, ch. 12.

${ }^{2}$ L. J. Williams, "The road to Tonypandy", in: Llafur, I (1973).

3 SWDN, 24 September 1910.

4 For example, ibid., 10 August.

5 Ibid., 12 April 1907; 5, 13, 18, 21, 29 and 30 August, 2 September 1910; 16 March, 2 and 30 May 1911.

${ }^{6}$ Ibid., 15 June 1911. 
that if terms were not conceded by 1 July then a further conference should meet on 3 July to order "drastic action". In Cardiff, however, events overtook the deliberations of the NTWF, which on 3 July in any case decided not to take sympathetic action. ${ }^{1}$ Before long, it became clear to the seamen's leader, Edward Tupper, that the strike would probably fail unless he could obtain the support at least of the tippers and trimmers: "I was getting desperate. Coal was thundering down hour after hour from the coal tips, into ships' holds and bunkers." To succeed, he had somehow to cut off the supply of coal, and the obvious way was to bring out the tippers and trimmers. Within two weeks, he was threatening to "declare a general stoppage for the port paralyse the town and industry". The leaders of the other occupations, however, were not willing to sacrifice their interests to those of the seamen, and a struggle emerged for the loyalty of the waterfront workers - which was eventually won by Tupper. ${ }^{3}$

Since the defeat of 1891 , the tippers had been reorganised by a different union, a fact of great significance to the Dockers' Union. In 1891, one strategic group - the trimmers - was lost; in 1898 the other - the tippers - was also lost, for when the BDC was transmuted into the Cardiff Railway Company, they joined the ASRS. ${ }^{4}$ This also meant that one strategic group was outside the aegis of the NTWF even if that body did call a sympathetic strike; and although the trimmers were eligible, they had not joined. The Dockers' Union - and the NTWF - was, in other words, left with the disparate miscellany of non-strategic occupations. The tippers' status as railwaymen was unclear, however, and this was leading to a dispute with the CRC as to whether or not they were included in the Conciliation Board established for railwaymen in 1907. On top of this, the tippers were pressing for a shorter working week. By June 1911 it seemed that restraint might collapse, and in the first week of the seamen's strike they were close to coming out themselves. In early July they were at crisis point, on the verge of an unofficial strike without giving notice. But J. H. Thomas arrived to take charge of the dispute, and the CRC was anxious to make a settlement so as to keep the tippers at work and isolate the seamen. By 8 July the tippers had been brought within the Conciliation Board and a compromise reached on the question of hours. Thomas was accordingly trying to keep the tippers at work,

1 Lovell, Stevedores and Dockers, pp. 156-58.

2 E. Tupper, Seamen's Torch (1938), pp. 39-40.

3 SWDN, 26 and 27 June 1911.

4 Ibid., 1 September 1899. 
maintaining that they could not afford to break their agreement. ${ }^{1}$ The seamen had, it seemed, been isolated. With the tippers apparently bought off, was it likely that those notorious moderates the trimmers would come out?

Tupper's position was not, therefore, a happy one. On 3 July he was threatening that "unless there is a settlement of our demands I will call out all the transport workers of the Bristol Channel". They were, he said, willing to come out on his signal; but when he "proclaimed" a strike, no one took any notice. ${ }^{2}$ The conference of the NTWF had decided not to call a sympathetic strike, and in the next few days the seamen's leaders in Cardiff were in a difficult position. But eventually Tupper's policy did succeed, whatever the NTWF might recommend. A number of incidents pushed the waterfront to revolt, and pressure built up for a sympathetic strike which the moderate union leaders could not contain. An objective analysis of the instrumentality of striking was unimportant alongside the psychology of mass movements. Even the trimmers were carried along. Partly it was a matter of racialism: hatred of the Chinese was being exploited by Tupper, and the first sympathetic strike occurred on 12 July when a ship was supplied with a Chinese crew. Then on 13th Tupper was summoned for inciting riot, and on 14th the dock gates were closed to pickets and the Lady Jocelyn depot ship moored outside the docks to supply blacklegs. All restraint collapsed. Of course, since about 1900 real wages had been stagnating, and the seamen's strike and Tupper's demagogy acted as a trigger of revolt, not only on the waterfront but throughout the town. The dock workers on 16th held a meeting in support of a sympathetic strike; the local secretary of the Dockers' Union when consulted said that he had to do as the executive told him, and that he had no instructions to call a strike - but personally he would have called one long ago. And the tippers' grievances re-emerged, for the adjoining dock companies had not offered the concessions granted by the CRC, and all tippers were pledged to a common policy. ${ }^{3}$

Order collapsed on 18 July when Tupper answered the charges against him and was remanded in custody.

"The seamen's strike [...] developed a ferocity which broke out in incendiarism, riot and bloodshed. For some hours in the after-

\footnotetext{
1 Ibid., 29 November and 1 December 1909; 31 May, 3, 4, 7 and 11 June, 6 and 8 September 1910; 23 January, 31 May, 5, 8, 9, 12, 15 and 19 June, 8, 10 and 11 July 1911; Tupper, Seamen's Torch, op. cit., p. 39.

2 SWDN, 3 and 4 July 1911.

${ }^{3}$ Ibid., 3-5, 8, 10-13, 17 and 18 July.
} 
noon mob law prevailed, the recklessness of the assailants breaking down all restraints and involving the district of the docks in a scene of wild disorder". 1

This was the turning point. The dockers - and the tippers and trimmers - were now in favour of sympathetic action. As J. Havelock Wilson put it, "the right and proper remedy is for every man to down tools at one and the same time". On 19 July this very largely happened: "the outstanding feature of the day was a general stoppage mission tour organised mainly by general labourers and other unskilled workmen and carried through with an astonishing success." All the workers in the import trades came out. More important was what would happen in the coal trade. The tippers in the ASRS were near revolt, whilst the majority of trimmers did hold an unofficial meeting which, despite all the efforts of the leaders, was in favour of an immediate strike. And at a mass meeting of all classes of dock workers addressed by Havelock Wilson a resolution was passed

"That seeing the Shipping Federation decline to hold a conference with the seamen's union officials and negotiate upon the lines of their claims, the working men of the port of Cardiff are of opinion that the time has arrived when all work in the port shall stop until the shipowners of Cardiff shall open up negotiations."

This made things very difficult for the union officials - particularly those of the CCTU and the Dockers' Union - who "were not associated with the decisions come to. [...] The men, in fact, have taken upon themselves to adopt a policy of 'down tools' and the officials are in a dilemma."2

By the 20th the docks were at a total standstill. The last trimmers ceased work, led by Tupper brandishing a shovel on a bicycle. A Strike Committee of all unions at the docks was formed to bring some order into the spontaneous rank-and-file movement. The union leaders had to attempt to control the unofficial strikes by their own members and organise the many who were not unionised. The situation was potentially dangerous, set for a repeat of the disaster of 1891.The officials had to sanction the strikes and called meetings to formulate a policy. Also on the 20th the Strike Committee met to ensure that a common front was maintained and no group isolated. It was resolved

"That we recommend the men now on strike at Cardiff to remain out until settlement is arrived at affecting every section of workers 
involved, $[\ldots]$ the full settlement to be submitted to a full conference for confirmation. Any section violating this will be repudiated."'1

Meanwhile, every Chinese laundry was attacked - the Chinese being expected to arrive in their thousands to act as blacklegs. And at a mass meeting of 40,000 chaired by Ernest Bevin, Tupper announced that "tonight the capitalist is against the wall. The weak has risen and is strong." The next day the strike spread far from the waterfront, again in a purely spontaneous way, to the foundries, wagon repairers, flour mills, railway shops, timber yards, breweries, laundries, rope works - and so on. In all, 15,500 men were on strike, excluding the seamen. ${ }^{2}$

This mass, spontaneous strike movement created a breakthrough. There was a total stoppage of the docks - unlike $1891-$, and even more so a new attitude amongst the employers - fear. Public order seemed to be collapsing. The riots at the docks had brought in police from other towns; now troops were called in, and on 21 July there was a running battle with police. The next day the ship-owners collapsed and gave the seamen most of what they wanted: union recognition, a fixed port rate, and a conciliation board. The generalising of the conflict had paid off admirably for the seamen. The key to the decision of the Shipowners' Association to recognize the National Sailors' and Firemen's Union was simple, "that however much we dislike Mr. Havelock Wilson and his kind, they are the people we have to deal with and that they have the sympathy of other trades unionists". ${ }^{3}$ What remained to be seen was how the other workers would fare. Their action had given the seamen a notable victory, but would they gain anything themselves, or had they - as in 1891 - been exploited by the seamen? In particular, could the Dockers' Union, relying essentially on the non-strategic occupations, get anything from the strike?

Tupper had certainly pledged that the seamen would remain out until every section that had sympathised had its grievances settled: "you don't think the seamen and firemen of Great Britain are going to sell their friends for a mess of pottage." And the Strike Committee was well aware of the dangers of sections being isolated and divided. Accordingly, it recommended that all men were to remain out until a settlement was reached for all, which was to be submitted to a full

1 Ibid., 21 and 22 July.

${ }^{2}$ Ibid., 21,22 and 25 July.

' Ibid., 22 and 24 July; Shipowners' Association, General Minute Book 1903-10, ff. 95-104. 
conference for confirmation. Once the seamen had won their demands, the Strike Committee on 23 July formulated proposals which "should be conceded before any section of the workers can be recommended to commence work": first, the official recognition of all unions involved; secondly, no action to be taken against any workman or union for stopping work without notice; thirdly, no victimisation; and finally, the employers to meet the men's representatives immediately to consider their grievances. Also, it was decided that no trade should return to work until all demands had been met. The Lord Mayor convened a conference of all the employers concerned to consider these proposals, and negotiations opened with the strikers' committee. Eventually, a joint committee of six from each side was appointed, under the chairmanship of the Lord Mayor. The width of the stoppage, the threat to public order and the insistence of the strikers had left the employers no option but to accept a general set of conditions to end the dispute. Certainly, the leading merchants would exert pressure upon other employers to give away more than they might wish in order to end a dispute which was threatening the whole export coalfield with disruption. It remained to be seen what the result would be when negotiations started on the specific grievances of each sector. ${ }^{1}$

As it was, a section of the waterfront was excluded even from the general terms for the return to work which were agreed on 27 July. Clauses two, three and four were accepted, with the understanding that they applied only to the present strike. But the first clause was greatly changed, which was to be important for the outcome on the waterfront:

"all the unions involved shall be officially recognised except that the C.R.C. and the T.V.R. are unable to accede to the requests made but are ready to grant the same recognition to their tippers as is granted by the railways of the country". ${ }^{2}$

Clearly, the tippers were not to get recognition but would get the same status as other railway workers; but what of the members of the Dockers' Union employed by the CRC? Presumably they would get nothing; or would they get the same terms as the tippers; or would they get full recognition from which the tippers alone had been excluded? The way was prepared for a renewal of conflict.

Further, it is essential to note that the return to work was made before the specific demands of each trade were settled. The seamen had on 22 July won a definite settlement; other workers on 27 th had ${ }^{1}$ SWDN, 22 and 24 July 1911.

${ }^{2}$ Ibid., 25-28 July. 
not, and once they returned to work it was an open question what in practice they would achieve. In particular, the Dockers' Union - comprised of non-strategic workers - lost the bargaining position provided by a total stoppage such as they could not achieve unaided. Ernest Bevin saw clearly that a return to work before demands were settled had seriously weakened his position. He was criticised by his members and argued in reply that
"the settlement of the strike was not satisfactory in the real sense of the word because the dockers had suffered more from strikes into which they had been drawn by others. He had fought in the conference room under the impression that there would be no definite settlement until all the grievances were tabled and considered, but when he found that the seamen and firemen had settled without any reservation he found the key to the situation gone so far as his men were concerned. [...] $\mathrm{He}$ denied absolutely that he was a guilty person in bringing about that particularly unsatisfactory settlement. His last appeal in the conference room was to hold out for the sake of his men $[\ldots]$; but he found that he did not succeed so he shut up."1

The power of the general stoppage had forced the previously intransigent ship-owners to give way as far as the seamen were concerned. The Dockers' Union alone, with its miscellany of unimportant occupations was, in the absence of a general stoppage, not powerful enough to break the intransigence of the CRC.

During August tension re-emerged between the CRC and Dockers' Union, resulting in an unofficial strike by 1,500 men. The area of contention was the clause in the July agreement concerning recognition. To the union, it denied full recognition only to the railway workers; but the CRC took the position that it had refused to recognise any union of any employees (which indeed seems to be the fairest interpretation of the words). When the CRC refused to negotiate on demands and took the position that while employees could ask for a meeting with the head of their own department, outsiders had no locus standi, the dockers came out on strike. The union application for increased wages was, as far as the CRC was concerned, the action of an outsider not entitled to make claims on behalf of the CRC employees, and was accordingly ignored. Tactics were then changed. Instead of claiming recognition under the July agreement, the dockers tried to bring themselves under the settlement made in August between the ASRS and the railway companies. This seemed to be a

1 Ibid., 5 August. 
good move. It would seem hypocritical to deny recognition to the Dockers' Union on the grounds that the employer was a railway company, while at the same time also denying it the rights obtained by the railway unions. But the change of tactics did not work. The dockers in the employ of the CRC achieved neither recognition nor parity with the tippers. The strike had to be called off, with only a few concessions in wages having been achieved. ${ }^{1}$

The position was better so far as the non-CRC dockers were concerned. They were given recognition under the July agreement, and in some cases the Dockers' Union also gained preference of employment, from the pitprop and timber importers, grain merchants, the steel company for its iron-ore dischargers, the Short Sea Traders' Association and the Stevedores' Association. ${ }^{2}$ For the first time, the Dockers' Union did have a measure of recognition and a stable base within the Cardiff docks. But it had gained less than it might from the 1911 strike. The CRC still withheld recognition, and this was vital, for it would be impossible to fix a definite port rate without the participation of the dock company. It is difficult to escape the conclusion that the initial nature of the strike - dictated by a spontaneous rank-and-file movement and not by union officials - had been unfortunate, while the attempt to get the most from the strike had been undermined by the way in which work had been resumed.

The Dockers' Union, of course, was no longer involved in the coal trade. How did the tippers and trimmers fare? The tippers had, it has been seen, been offered inclusion in the 1911 Conciliation Board, presumably with the aim of keeping them at work and disuniting the workers. Certainly, once the crisis was over the CRC was very loath to implement the agreement. Final settlement came only at the end of 1912, and only after the tippers had handed in notice of their intention to strike. ${ }^{3}$ The trimmers had in 1911, for the first time in their history, struck work. In 1907 they had, by playing off the coal shippers against the ship-owners, secured a favourable tariff. In 1911 they made further changes the condition of return, but their demands were directed as much against the foremen as the employers. Since the docks were disrupted anyway, their decline in strategic importance was not exposed and the CCTU immediately returned to its stance of moderation. When settlement was reached in August 1911, it was indeed agreed

${ }^{1}$ Ibid., 4, 5, 7, 15-17, 23, 25, 26 and 28-31 August, 24 November 1911; 22, 26 and 28 February 1912 .

${ }^{2}$ Ibid., 11, 21 and 23 December 1911; 6 and 17 January 1912; 26 February, 16 April, 28 May, 11 June and 11 July 1913.

${ }^{3}$ Ibid., 13, 20, 23, 24 and 27 November, 7 and 11 December 1911; 27 August and 4 November 1912. 
"that all the modifications and concessions which may be made and granted in the tariff of the port during these negotiations are made and granted on the distinct understanding that the trimmers do not join in a sympathetic strike. If they do join in such a strike the whole of the modifications and concessions will be withdrawn."

In 1913 the NTWF mounted a campaign to expand its activities, and in particular to bring the CCTU within its ranks. This the trimmers refused to do. The NTWF saw the adherence of the CCTU as absolutely essential to its local position. But much as militant unionists might complain of the "want of class loyalty" of "tame labour leaders like the Cardiff Coaltrimmers' Executive who always play into the hands of the employing class", they in fact had a more realistic appraisal of their position. The NTWF seemed to think that by controlling trimming they would control the whole docks, but this was doubtful. The position of the CCTU relied upon the support of the coal-owners against the ship-owners rather than upon the intrinsic importance of trimming - and this demanded moderation rather than militancy and sympathetic strikes. ${ }^{1}$

So the union pattern as it existed in 1914 was not simple: ASRS tippers (who had been granted a conciliation board) tipped coal to be trimmed by members of the local trimmers' organisation (which was fully recognised by the joint employers), whilst most other dock workers were organised by the Dockers' Union, some employers giving the union recognition and preference, while the CRC remained firmly opposed to collective bargaining and recognition. As yet the NTWF had not been of great local significance - certainly not in the strike of 1911 -, but the need for co-ordination was overwhelmingly apparent. It was rare for all the labour of a port to be in a single union. In Cardiff there was certainly a plethora of competing unions, which were sometimes outright hostile to each other, sometimes acting independently, sometimes working in consultation - but always affecting one another by their actions. It would be interesting - although it cannot be done here - to look ahead to see what the outcome would be in the inter-war years with the formation of the Transport and General Workers' Union, the grouping scheme on the railways, and the decline in the coal trade which had been the basis of the trade of Cardiff. Perhaps another historian will some time consider these questions.

1 Daunton, "The Cardiff Coal Trimmers Union"; CCTU, Minutes 1910-12, 4 August 1911; SWDN, 12 April 1912. 


\section{III}

The general point stressed in the introduction was the importance of the choice by both the employers and employees between a general or a specific approach to any dispute. The employers might stress a general principle in order to widen the dispute away from the specific claims of one sector. This was what they tried to do in 1890 over the railwaymen's strike: employers besides those immediately involved saw it as a good opportunity to face the other unions with whom they were sooner or later bound to come into conflict. But the unions saw the strategy very clearly and kept firmly to the specific demands of the railwaymen. Another possibility was that a weak group of workers would seek to generalise the conflict, in the knowledge that alone they could achieve little. This was very dangerous, for the outcome might be simply a widening of the area of defeat. It was the policy adopted by the seamen in 1891 and 1911 - in one case with disastrous consequences, and in the other with mixed results. Alone, the seamen were too weak to achieve any permanent breakthrough and they were virtually obliged to bring other workers out on strike. In 1891 they brought the dockers out, and both dockers and seamen were shattered. In 1911 they brought the dockers out again, won a remarkable victory for themselves and a less satisfactory achievement for the dockers.

The key to events in 1891 and 1911 was the action of the seamen. After 1911 the leading sector, as it were, moved inland from the sea to the valleys. The occupation behind which others followed was now the miners. The inter-union relations considered here involved the waterfront: the seamen, the tippers, the trimmers and other dockers. But in 1914 the scope was widened when the NTWF joined with the National Union of Railwaymen and the Miners' Federation of Great Britain in the Triple Alliance. ${ }^{1}$ It is easy to see the attraction of the Triple Alliance in South Wales. The South Wales ports were predominantly coal ports, and the economy of South Wales was geared to producing coal for export. The whole life of ports such as Cardiff and Barry was ruled by coal, so that any strike by the miners was bound to have serious impact upon the port workers. Similarly, any disruption at the ports would very swiftly affect the miners. The bulk of output was for export, and in the narrow mining valleys little coal could be stock-piled: the output was loaded direct into railway wagons and taken to the coast for shipment. Any delay to shipments would lead to a cessation of production. And of course any strike on

${ }^{1}$ G. A. Phillips, "The Triple Industrial Alliance in 1914", in: Economic History Review, Second Series, XXIV (1971). 
the railways would have an immediate effect upon the other groups. So cessation of work by any of the categories - waterfront, railwaymen, miners - would seriously disrupt the others. And of course the dock companies were also railway companies, employing the same tactics against Dockers' Union and ASRS.

However, systematic relations such as were implied by the Triple Alliance were possible only when each section had a stable organisation - and it was only around 1911 that this was achieved. The fact of their having an impact upon each other was not new; what was new and important was that those relationships could now be systematised and formalised. The railwaymen had moved from their Pyrrhic victory of 1890 to the disaster of 1900-01, from which they recovered in the all-grades movement of 1907 and the national strike of 1911. The miners, for their part, from 1898 on started to move from moderation to militancy, a process culminating in the Cambrian dispute of 1910 and the national strike of 1912. In the aftermath of the strikes of 1890-91 an alliance was scarcely practicable: the seamen and dockers were left unorganised, with the exception of the trimmers; the miners' organisation was limited to representation on the slidingscale committee; the railwaymen's organisation became split between different companies and grades, scarcely able to synchronise their own actions. It was between 1910 and 1912 that dockers, railwaymen and miners entered a new phase which eventually brought them together in a mutual alliance. The pace was now set not by the seamen, who, in fact, became increasingly alienated: they left the NTWF, which then sponsored an alternative union, they refused to support the miners in 1926 and indeed backed the breakaway Miners' Industrial Unions, and they were expelled from the TUC. ${ }^{1}$ Rather the lead came from the miners, the final outcome being the General Strike of 1926. But that, like the subsequent history of the waterfront, is another story.

1 F. J. Lindop, "A History of Seamen's Trade Unionism to 1929" (M.Ph. London, 1972); B. Mogridge, "Militancy and inter-union rivalries in British shipping, 1911-1929”, in: International Review of Social History, VI (1961). 